\title{
Echinoderms from Middle and Upper Ordovician Rocks of Kentucky
}

GEOLOGICAL SURVEY PROFESSIONAL PAPER $1066-\mathrm{K}$

Prepared in cooperation with the

Commonwealth of Kentucky,

University of Kentucky,

Kentucky Geological Survey

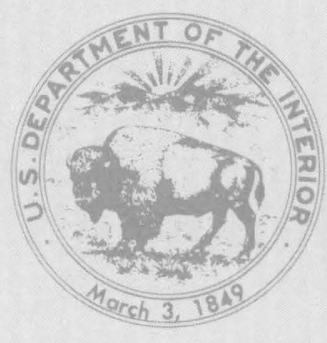





\section{Echinoderms from Middle and Upper Ordovician Rocks of Kentucky}

By RONALD L. PARSLEY

CONTRIBUTIONS TO THE ORDOVICIAN PALEONTOLOGY OF KENTUCKY AND NEARBY STATES

Edited by JOHN POJETA, JR.

GE OLOGICAL SURVEY PROFESSIONAL PAPER 1066-K

Prepared in cooperation with the

Commonwealth of Kentucky,

University of Kentucky,

Kentucky Geological Survey

Descriptions and illustrations of nine species of Stylophora,

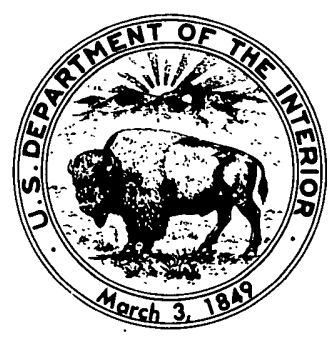

Paracrinoidea, Inadunata, Cyclocystoidea, and Rhombifera 
UNITED STATES DEPARTMENT OF THE INTERIOR

JAMES G. WATT, Secretary

\section{GEOLOGICAL SURVEY}

Doyle G. Frederick, Acting Director

Library of Congress catalog-card No. 81-607882

For sale by the Superintendent of Documents, U.S. Government Printing Office Washington, D.C. 2.0402 


\section{CONTENTS}

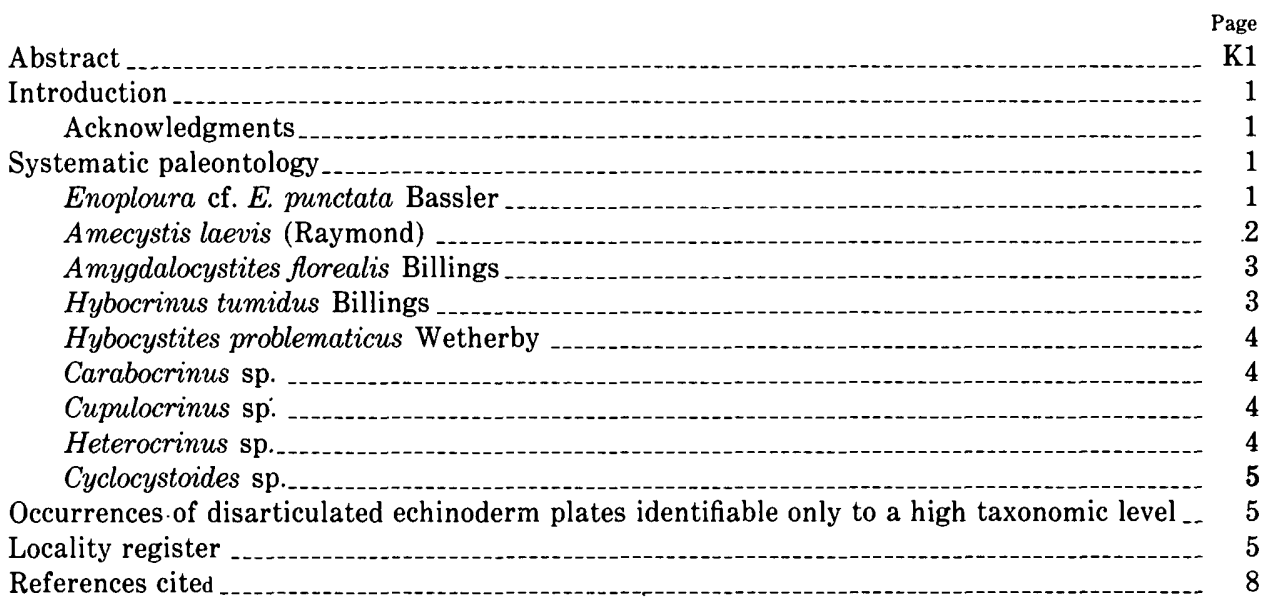

\section{ILLUSTRATIONS}

Plate 1. Specimens of Amecystis, Amygdalocystites, Cupulocrinus, Heterocrinus, Hybocrinus, Hybocystites, Carabocrinus, Enoploura, and Cyclocystoides.

Figure 1. Ventral (anal) side of a partly reconstructed specimen of Amecystis laevis

(Raymond)

\section{SYSTEM OF MEASUREMENT UNITS}

The investigations underlying this series of reports were made over a period of years, and distances and stratigraphic measurements appear fairly uniformly in English units. Measurements of fossil specimens, on the other hand, follow the long-standing convention of appearing in metric units. Because of the dates of the investigations and the amount of resulting data, the English measurements have been retained. Conversions to metric units may be made by using the following conversion table:

To convert English unit:

Mile (mi)

Foot (ft)

Inch (in.)
To metric unit:

Kilometer (km)

Meter (m)

Centimeter (cm)
Multiply by: 1.61 .305 .394 



\title{
ECHINODERMS FROM MIDDLE AND UPPER ORDOVICIAN ROCKS OF KENTUCKY
}

\author{
By Ronald L. PARSLEY ${ }^{1}$
}

\begin{abstract}
The Middle and Upper Ordovician limestones of Kentucky, especially the Lexington Limestone, have yielded a diverse silicified echinoderm fauna, including: Stylophora-Enoploura cf. E. punctata, Paracrinoidea-Amygdalocystites; Crinoidea, Inadunata-Hybocrinus tumidus, Hybocystites problematicus, Carabocrinus sp., Cupulocrinus sp., Heterocrinus sp.; Cyclocystoidea-Cyclocystoides sp. A rhombiferan cystoid, Amecystis laevis, from the Edinburg Formation, Virginia, is also discussed. No new taxa are introduced.
\end{abstract}

\section{INTRODUCTION}

The Lexington Limestone and adjacent Middle to Upper Ordovician formations of Kentucky have yielded a rich and varied silicified fauna. Most of the echinoderm material has come from the Curdsville Limestone Member of the lowermost part of the Lexington Limestone, although some is from stratigraphically higher Middle and Upper Ordovician formations. Echinoderm specimens are usually poorly preserved because of the coarseness of the silicification, and they are generally damaged by the etching process.

Despite the limited number of identifiable (articulated) specimens, the diversity of higher taxa is considerable, which is typical for Middle Ordovician rocks. Mitrate stylophorans, paracrinoids, inadunate crinoids, and cyclocystoids are discussed herein. A rhombiferan cystoid from the Edinburg Formation, Tumbling Run, Va., is also included. Ordovician edrioasteroids and asteroids from Kentucky have been discussed by Bell (1979) and Branstrator (1979), respectively.

A few of the collections contain many disarticulated crinoid columnals and various types of disarticulated thecal plates. The former are generally unidentifiable and are here recorded by formation and collection number at the end of the paper.

In spite of the rather high diversity of echinoderms, especially in the lower part of the Lexington Limestone, the actual number of echinodermal remains seems to be rather low. Of the 1,086 collections made, only 84 , or slightly less than 8 percent, yielded echinoderm remains. Although there is a collecting bias for silicified mollusks and brachiopods (John Pojeta, Jr., oral commun., 1975), it is puzzling why presumed shallow-water,

'Tulane University, New Orleans, La. normal marine echinoderms are not more commonly found with brachiopods, mollusks, bryozoans, etc., in these collections. Preservation alone does not seem to be an adequate explanation for the paucity of echinoderms, nor does the fact that many Ordovician echinoderms, e.g., edrioasteroids and crinoids, had a definite tendency to form small colonies on the sea bottom (see Springer, 1911, p. 13, concerning the crinoid Hybocystis). Most echinoderms partly or entirely disarticulate after death and are spread over the sea floor by currents. The question of their poor representation at this time is unresolved.

Although no new taxa are recognized in this study, several specimens have enhanced our knowledge of known genera, notably the specimens of the mitrate Enoploura and the rhombiferan Amecystis.

Many of the genera and species of Echinodermata found in the Lexington Limestone also occur in the Kirkfield Limestone of Kirkfield, Ontario, Canada, and in the Hull Beds (and in lesser numbers in the Sherman Fall Beds) of the Ottawa, Ontario, area. These units seem not only to span essentially the same time period but also to have a similar paleoenvironmental setting.

\section{ACKNOWLEDGMENTS}

I wish to thank John Pojeta, Jr., U.S. Geological Survey, Washington, D.C., for selecting me to work on this material. James C. Brower, Dept. of Geology, Syracuse University, Syracuse, N.Y., identified some of the crinoids. The text figure was drawn by Susan Foster, Newcomb College, Tulane University, New Orleans, La. Dennis Greig of Chevron, U.S.A., New Orleans, La., took the SEM photographs with his company's instrument.

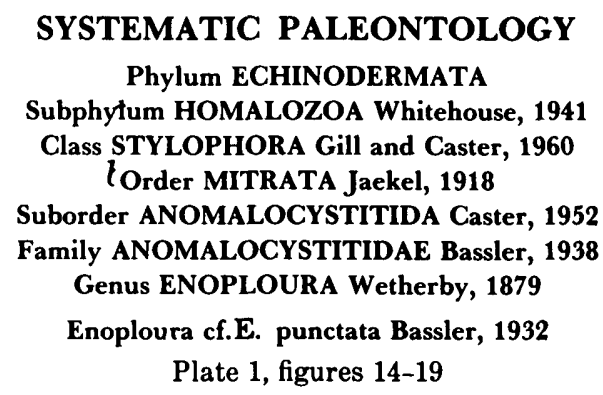


Enopleura [sic] punctata Bassler, 1932, p. 218, pl. 18, fig. 9:

Enoploura punctata Bassler, Bassler and Moodey, 1943, p. 157: Parsley 1969, p. 69-75, pl. 2, figs. 1-7.

Diagnosis. - Carapace prosopon scaly punctate; aboral lip thick and evenly rounded, distal spines thick, unbowed, terete. Styloid blades not greatly expanded.

Description.-Enoploura punctata has a subrectangular, convexo-concave theca which thickens proximally towards the subvective aulacophore. Articulated spines are attached at the distal corners of the theca; they are terete (typical of this Middle Ordovician species), rather than compressed and slightly curved (typical of Late Ordovician species). Along the distal margin, a heavy, evenly curved unornamented lip projects from the lower (plastron) surface. (Late Ordovician species of Enoploura have a thin, often distally denticulate lip, which is commonly ornamented with veinlike depressions on its upper surface.)

The aulacophore is divided into three sections: (1) a proximal tetramerous part consisting of 10 to $11 \mathrm{seg}$ ments, usually having several of the proximal segments inserted into the theca; (2) a distal trimerous part, composed of a keel-shaped basal ossicle and paired covering plates over the food groove, which is on the upper surface of the basal ossicle; and (3) an intermediate section, the styloid, which is made up of highly modified distal aulacophore segments, the basal ossicles (three) being projected laterally and ventrally into broad flat blades. These blades serve as a base for the distal aulacophore, which was held above the animal for subvection (Ubaghs, 1967, p. 532-535; Parsley, 1967, p. 172-173; Parsley and Caster, 1975, p. 1225-1226).

Discussion. - The material studied for this report consists of seven incomplete specimens, among which is a single nearly complete individual (pl. 1, fig. 17). These specimens, which can only be tentatively assigned to the species $E$. punctata, are generally poorly preserved. Plate outlines are blurred because of silicification, and only gross external and some internal features are observable.

The position of the gut is suggested by what appears to be mud infilling; this mud probably was emplaced soon after the death of the animal. The gut seems to have extended from the aulacophore opening in a diagonal direction along the septum on the plastron floor to the distal right corner of the theca, where presumably the anus opened into the central (cloacal cavity?) opening. Almost all internal detail has been obliterated because of the coarseness of silicification.

Perhaps the most interesting aspect of this material is that several specimens (pl. 1, figs. 17, 18) on file seem to have taken refuge under Rafinesquina shells, which were lying convex-side upward on the substrate. The theca and most of the proximal aulacophore of each specimen are under the respective shells, and the styloid and distal aulacophore of one specimen extend upwards over the top of the animal and the brachiopod shell in what appears to be close to the habitus feeding position. The positions of the specimens seem to be deliberate, rather than being the result of fortuitous preservation.

Localities and materials.-Curdsville Limestone Member, Lexington Limestone: USNM 245193-245195 (pl. 1, figs. 14-16), USGS loc. 6134-CO; USNM 247881 (pl. 1, fig. 17), USGS loc. 6134-CO; USNM 247883 (pl. 1, fig. 19), USGS loc. 7785-CO. Clays Ferry Formation: USNM 247882 (pl. 1, fig. 18), USGS loc. 6143-CO.

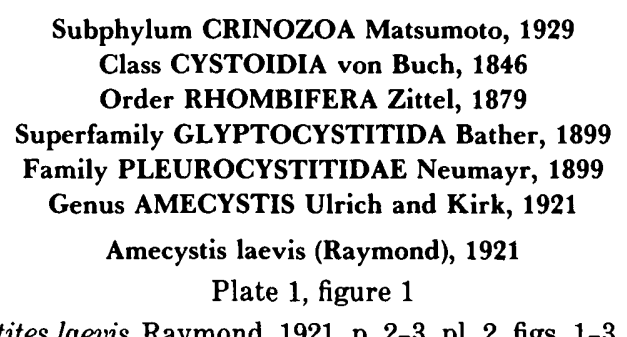

Pleurocystites laevis Raymond, 1921, p. 2-3, pl. 2, figs. 1-3.

Amecystis Laevis Ulrich and Kirk, 1921, p. 147-148: Parsley, 1970, p. 192-194, pl. 29, figs. 1-5, pl. 30, figs. 5, 6: Broadhead, 1974, p. 670-673; Broadhead and Strimple, 1975, p. 318.

Diagnosis.-Amecystis with flattened, evenly sagittate theca; thecal plates thin, smooth, or with pustulose prosopon.

Discussion. - This species is represented herein by a single specimen that shows the ventral (anal) surface of the theca and part of the column (pl. 1, fig. 1; text-fig. 1). Except for a few proximal plates, the brachioles are missing. The specimen is significant in that it clearly shows the entire polyplated periproctal area and the ventral thecal plates adjacent to the brachioles. The number and geometry of the distal ventral thecal plates have been subject to controversy (Parsley, 1970, p. 189; Broadhead, 1974, p. 671, text-fig. 1; Broadhead and Strimple, 1975, p. 313, fig. 1, p. 318).

The problem primarily concerns the presence or absence of oral plate 06 and its relationships to 01 and 07 , which are identifiable in all pleurocystitids. In $A m$ ecystis, plate 01 underrides 07 , so that 07 is quite thin and is seemingly susceptible to postmortem fracture. The ease of fracture probably is enhanced by the additional thinning of 07 where the conduits for the hydropore and gonopore traverse its undersurface. Apparently, fracturing accounts for the presence of an " 06 " plate in this genus. In some specimens, 06 may indeed split from 01 early in ontogeny, and the presence of 06 would then be an example of intrageneric variation (see Sinclair, 1948, p. 311; Kesling, 1961, p. 66; Paul, 1967, p. 107; Parsley, 1970, p. 154).

Plates L1 and L4 are considerably attenuated towards the sagittal axis. In most specimens the thinned parts of these plates fracture, and these breaks can resemble sutures, resulting in the identification of spurious plates.

The ornamentation on the marginal plates is unique to this specimen, but to establish a new species on this 


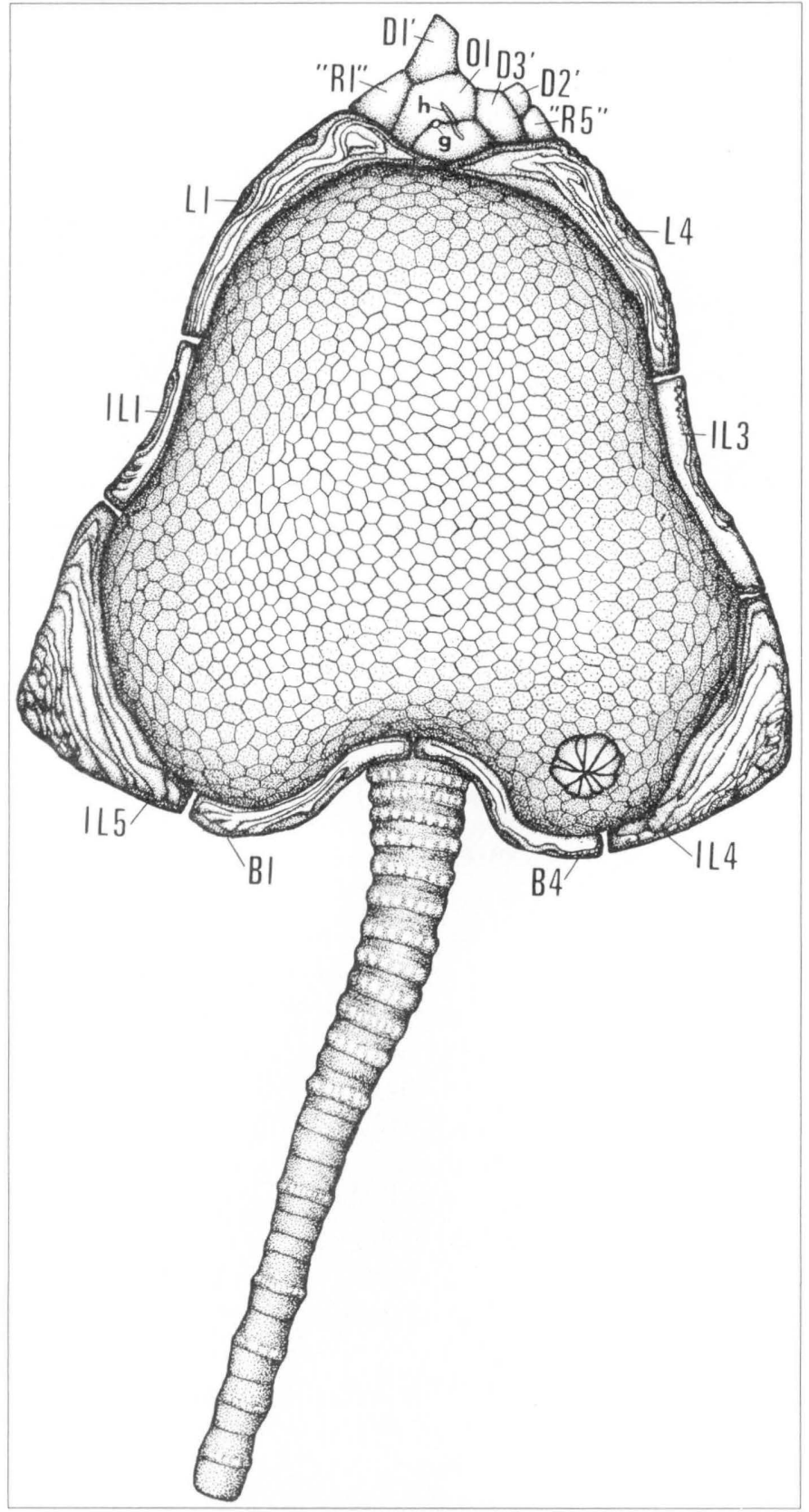

Figure 1.-Partial reconstruction of the ventral (anal) face of Amecystis laevis. Plate terminology is that used for glyptocystitid rhombiferans: B, basals; IL, infralaterals; L, laterals; R, radials; O, orals; D, distals (see Parsley 1970, p. 140); h, hydropore slit; g, gonopore. The plate that shares the hydropore and gonopore with 01 is 07 . The large tesselated surface is the greatly expanded periproct, the anal pyramid being just above the suture between B4 and IL4.

feature alone, with no knowledge of the opposite face, seems unwise.

Locality and materials. - Edinburg Formation, Tumbling Run, near Strasburg, Va.; cobbly limestone facies nearest to junction of road paralleling creek with State Route 11: USNM 245181.
Subphylum PARACRINOZOA Parsley and Mintz, 1975 Class PARACRINOIDEA Regnéll, 1945

Order COMAROCYSTITIDA Parsley and Mintz, 1975 Family AMYGDALOCYSTITIDAE Jaekel, 1900 Genus AMYGDALOCYSTITES Billings, 1854 Amygdalocystites florealis Billings, 1854 Plate 1, figures 2, 3

Amygdalocystites florealis Billings, 1854, p. 270-271, figs. 4-6; Billings, 1857, p. 289; Billings, 1858, p. 63-64, pl. 6, figs. 1a-e; Billings, W. R., 1883, p. 51-52; Wilson, 1946, p. 9-10, pl. 1, figs. 1-2; Parsley and Mintz, 1975, p. 49-51, pl. 4, figs. 1-7, pl. 5, figs. 1-7, textfig. 1 .

Amygdalocystis [sic] florealis Billings, Haeckel, 1896, p. 106-107, fig. 15; Bather, 1900, p. 57, fig. 19.

Amygdalocystites tenuistriatus Billings, 1854, p. 271, fig. 9; Billings, 1857, p. 289-290; Billings, 1858 , p. $64-65$, pl. 6 , figs. $2 \mathrm{a}-\mathrm{f}$.

Amygdalocystites huntingtoni Wetherby, 1881, p. 177, pl. 5, fig. 3.

Ottawacystites laevis (Billings, W. R.) Wilson, 1946, p. 14, pl. 3, figs. $1 \mathrm{a}-\mathrm{b}$.

Diagnosis.-Amygdaloid theca with two recumbent arms; thecal plates with expending rays expanding from rounded central boss to plate corners; smaller rays extending from boss to bisect plate facets.

Discussion.-Amygdalocystites was first reported in the Lexington Limestone by Wetherby (1881) as $A$. huntingtoni Wetherby; Parsley and Mintz (1975, p. 50) placed Wetherby's species in synonomy with A. florealis Billings. Two specimens of $A$. florealis are included in this report. Both have the offset and bent proximal column, theca, and the recumbent arms. One specimen, USNM 245183 (pl. 1, fig. 3), has poorly preserved exothecal pinnules lying over the theca. Species-level identification of these poor specimens is possible because of the radial ornament on a few of the thecal plates.

These specimens clearly show the proximally reflexed column, which in life canted the theca at an angle to its longitudinal axis and resulted in the offset peristome being in an uppermost and horizontal position or very close to it.

Locality and materials._Curdsville Limestone Member, Lexington Limestone, USGS loc. 6134-CO: USNM $245182,245183$.

Class CRINOIDEA J. S. Miller, 1821

Subclass INADUNATA Wachsmuth and Springer, 1885

Order HYBOCRINIDA Jaekel, 1918

Family HYBOCRINIDAE Zittel, 1879

Genus HYBOCRINUS Billings, 1857

Hybocrinus tumidus Billings, 1857 Plate 1, figures 6, 9

Hybocrinus tumidus Billings, 1857, p. 275; Billings, 1858, p. 28, pl. 2, figs. 1a-c; Springer, 1911, p. 24, pl. 5, figs. 1-5; Wilson, 1946, p. 31.

Discussion. - The new material available is a single partly preserved theca that has the proximal parts of the arms attached. The crenulated anal (X) plate is visible, although it is somewhat worn. Identification of this specimen is based on the nature of the anal plate (see 
Springer 1911, p. 24) and the rather globular outline of the theca. No new morphological features have been observed on the specimen.

Locality and material. - The single specimen USNM 245186 is from USGS loc. 5083-CO, Curdsville Limestone Member, Lexington Limestone.

\author{
Genus HYBOCYSTITES Wetherby, 1880 \\ Hybocystites problematicus Wetherby, 1880 \\ Plate 1, figures 7, 8, 10
}

Hybocystites problematicus Wetherby, 1880 , p. 150-152, pl. 5, figs. 1 , 1a-c; Carpenter, 1882, p. 307-312, pl. 9, figs. 6-24.

Hybocystis [sic] problimaticus Wetherby emend. Parks, 1908, p. 232-234, pl. 2, figs. 1-3, 5 .

Hybocystis [sic] eldonensis Parks, 1908, p. 234-235, pl. 2, fig. 4; Springer 1911, p. 13, 19-20, pl. 2, figs. 1-10.

Discussion.-This species is represented by two incomplete thecae and some disarticulated plates. In neither specimen is there any evidence of a column of the distal ends of the arms. Identification is based on the presence of recumbent arms over the radials and the distinctive crenulate ornament of the thecal plates. Among the disarticulated plates, the radials are especially identifiable (pl. 1, fig. 8).

This species has the tendency to form colonies that are very closely spaced so that 100 or more individuals may have lived in an area of several square feet (Springer, 1911, p. 13). Within one such colony, Springer (1911) described specimens attributed to $H$. problematicus and H. eldonensis. Springer (1911, p. 19-20) correctly pointed out that the identification as two species was probably due to differences in size and growth between the two specimens and that both specimens should be placed under a single species. Although he declined to synonymize the two species, it is done herein.

Hybocystites is one of the most unusual of the crinoids in that three of the arms are short (five or six segments long), whereas the two anterior lateral arms are recumbent and fit into grooves that extend across the radials and sometimes even onto the basals and column in mature specimens.

Localities and materials.-Specimens USNM 245187 (pl. 1, fig. 7) and USNM 245189, (pl. 1, fig. 10) are from USGS loc. 5083-CO, which is at the base of the Curdsville Limestone Member, of the Lexington Limestone. Disarticulated plates such as USNM 245188 (pl. 1, fig. 8), USGS loc. 7785-CO, Curdsville Limestone Member, Lexington Limestone, are also found in localities 5084-CO, 5101-CO, and 7784-CO of the same stratigraphic unit.

The same species of Hybocystites and Hybocrinus are found in the Hull Beds of Ontario. Many other Trentonian echinoderms are common to the Curdsville Limestone Member and Hull Beds, clearly indicating their similarity in paleoenvironment and probable time equivalence.

\author{
Suborder CYATHOCRINOIDEA Bather, 1899 \\ Family CARABOCRINIDAE Bather, 1899 \\ Genus CARABOCRINUS Billings, 1857 \\ Carabocrinus sp. \\ Plate 1, figures 11, 12
}

Discussion. - Disarticulated plates can be assigned to Carabocrinus because of characteristic raised radiating ridges on their outer surfaces. Radial and basal plates are present. Identification of these plates to the species level is not possible; however, C. vancortlandi Billings, C. radiatus Billings, and C. ovalis Miller and Gurley have all been previously reported in the Curdsville Limestone Member of the Lexington Limestone (see Bassler and Moodey, 1943, p. 306). The three named species may be synonyms of a single species, at least in the Curdsville. However, the material at hand is of no value in determining this.

Locality and materials. - USGS loc. 7785-CO, Curdsville Limestone Member, Lexington Limestone: USNM 245190 (pl. 1, fig. 11); USNM 245191 (pl. 1, fig. 12).

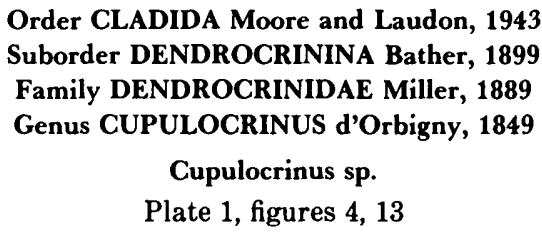

Discussion.-Species-level identification of the two figured specimens is uncertain, as the diagnostic features of the anal sac are not preserved. The specimens probably are either $C$. humulis (Billings) or C. jewetti (Billings), both of which were previously reported from the Curdsville Limestone Member of the Lexington Limestone (Springer, 1911). The short wide primibrachs are typical of Cupulocrinus, and this feature serves to distinguish it from the closely related coeval genus Dendrocrinus.

Locality and materials.-Curdsville Limestone Member of the Lexington Limestone, USGS loc. 5072-CO: US NM 245184 (pl. 1, fig. 4) and USNM 245192 (pl. 1, fig. 13).

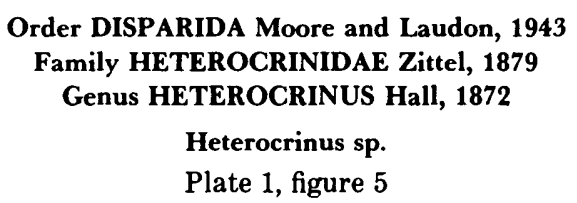

Discussion. - This form is known from a single incompletely preserved specimen, which shows part of the monocyclic theca, part of the proximal column, and the proximal parts of several arms (primibrachs), one arm with the primary axillary. Although several Middle Ordovician species of Heterocrinus are known, Heterocrinus tenuis Billings, reported from Quebec and Ontario (by Billings, 1857, and Wilson, 1946), is the most likely species name for this specimen.

Locality and materials.-Grier Limestone Member, Lexington Limestone, USGS loc. 4946-CO: USNM 245185 (pl. 1, fig. 5). 
Subphylum ECHINOZOA Matsumoto, 1929

Class CYCLOCYSTOIDEA Miller and Gurley, 1895

Family CYCLOCYSTOIDIDAE Miller, 1892

Genus CYCLOCYSTOIDES Salter and Billings, 1858

Cyclocystoides sp.

Plate 1, figure 20

Discussion.-At several localities, distinctive, disarticulated submarginal plates of Cyclocystoides have been found in considerable numbers. Plates having two, and, less commonly, three radial ducts are present. At least five species of Middle Ordovician cyclocystoids (all genus Cyclocystoides) are known in North America, but this is their first reported occurrence from Kentucky. The rather poor preservation of the plates precludes specific identification.

Localities and materials.-Salvisa Bed, Perryville Limestone Member, Lexington Limestone, USGS loc. 5015-CO: USNM 247884 (pl. 1, fig. 20). Other USGS localities where cyclocystoid plates have been found: 6409-CO, Calloway Creek Limestone; 6410-CO, 6411-CO, Ash-lock Formation; and 6416-CO, Grant Lake Limestone.

\section{OCCURRENCES OF DISARTICULATED ECHINODERM PLATES IDENTIFIABLE ONLY TO A HIGH TAXONOMIC LEVEL}

The following list gives USGS locality numbers arranged by the formations that contain echinoderm remains. Most of the remains are short segments of crinoid columnals or individual columnals. A locality number indicates the occurrence of crinoid columnals or short column lengths, unless otherwise stated.

Camp Nelson Limestone: 5079-CO, 7835-CO, 7863-CO, 7875-CO.

Tyrone Limestone: $6035-\mathrm{CO}, 6036-\mathrm{CO}, 6037-\mathrm{CO}, 6039-$ $\mathrm{CO}, 6041-\mathrm{CO}, \quad 6042-\mathrm{CO}, 6133-\mathrm{CO}, \quad 7795-\mathrm{CO}$, 7886-CO.

Lexington Limestone:

Curdsville Limestone Member: 4073-CO, 4940-CO (Cupulocrinus), 5022-CO, 5069-CO, 5072CO (Cupulocrinus), 5084-CO, 5101-CO (crinoid thecal plates, Hybocrinus, Carabocrinus), 6131-CO (crinoid thecal plates, Carabocrinus? plate), 6134-CO (crinoid thecal plates, mitrate), $6135-\mathrm{CO}$ (crinoid thecal plates), 6751-CO, 7782-CO (Carabocrinus plates), 7784-C0, 7785-CO (mitrates, crinoid thecal plates, Carabocrinus, Hybocrinus plates, small Cupulocrinus), 7817-CO.

Logana Member: 7791-CO.

Grier Limestone Member: 4073-CO, 4852-CO, 4874-CO, 4928-CO, 4959-CO, 5074-CO, 5093-CO, 7792-CO.
Perryville Limestone Member: 5015-CO (partly preserved circlet of cyclocystoid plates, disarticulated cyclocystoid plates), 6136$\mathrm{CO}, \quad 6138-\mathrm{CO}, 6715-\mathrm{CO}$ (cyclocystoid plates), 7842-CO.

Tanglewood Limestone Member: D-1200-CO, D-1202-CO, D-1206-CO, 7783-CO, 7787$\mathrm{CO}, 7793-\mathrm{CO}, 7796-\mathrm{CO}, 7809-\mathrm{CO}, 7811-\mathrm{CO}$, 7821-CO, 7823-CO.

Millersburg Member: 6144-CO, 7079-CO (crinoid thecal plates), $7353-\mathrm{CO}, 7790-\mathrm{CO}$.

Clays Ferry Formation: D-1172-CO, D-1173-CO, 6128$\mathrm{CO}, 6142-\mathrm{CO}, 6143-\mathrm{CO}$ (mitrate), 7044-CO, 7348-CO, 7349-CO, 7350-CO, 7458-CO, 7812-CO.

Point Pleasant Tongue: 6699-CO (crinoid holdfasts), 7824-CO (crinoid thecal plates), 7825-CO, 7830-CO.

Kope Formation: 7834-CO.

Grant Lake Limestone: $6416-\mathrm{CO}$ (crinoid thecal plates, cyclocystoid plates).

Ashlock Formation: 6043-CO, 6410-CO (cyclocystoid plates), 7794-CO, 7843-CO;

Gilbert Member: 6411-CO (cyclocystoid plates), 6412-CO (cyclocystoid plates, crinoid thecal plate).

Whitewater Formation: 7802-CO.

Dillsboro Formation: 6140-CO.

\section{LOCALITY REGISTER}

This locality register supplements that published by Pojeta (1979) in chapter A of this series, which contains the details of the numbering and the methods of notation. Only localities not mentioned in chapter $\mathrm{A}$ are included here; therefore, refer to chapter A for any locality numbers used in this paper that are not in this register.

Collection number ….... 4928-CO*.

Geographic location ..... The same as for 4929-CO.

Coordinates _...-...-... Do.

Formation Limestone.

Stratigraphic position _-- $22 \mathrm{ft}$ below the base of the Brannon Member, Lexington Limestone.

Silicified ..................... Yes (40 lbs).

Quadrangle name........ Salvisa, Ky.

Section name

Section number

Collection number ------- 4946-CO.

Geographic location -...- The same as for 4940-CO.

Coordinates _........... Do.

Formation ................ Float in lower part of the Grier Limestone Member, Lexington Limestone.

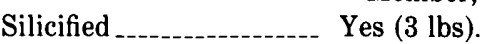

Quadrangle name...-.-. Salvisa, $\mathrm{Ky}$.

Section name $\quad$ Salvisa $B$

Section number --------- 176. 
Collection number Geographic location

5074-CO*

\begin{tabular}{|c|c|}
\hline & $\begin{array}{l}\text { Pike, north of Gainesway, Ky., and } 2 \mathrm{mi} \\
\text { south of intersection with Cooper Rd. }\end{array}$ \\
\hline Coord & $15.5 \mathrm{~mm}$ east, $545 \mathrm{~mm}$ north. \\
\hline Formation & $\begin{array}{l}\text { Grier Limestone Member, Lexington } \\
\text { Limestone. }\end{array}$ \\
\hline Silicified. & Yes (15 lbs). \\
\hline Section name & Tates Creek Rd. quarry. \\
\hline Collection number & $5079-\mathrm{CO}^{*}$. \\
\hline Geographic location & The same as for $7875-\mathrm{CO}$. \\
\hline Coordinates & Do. \\
\hline Formation & Camp Nelson Limestone. \\
\hline Silicified _...--.--_-_. & Yes (10 lbs). \\
\hline Quadrangle name & Wilmore, Ky. \\
\hline Section name & High Bridge. \\
\hline Collection number & 508 \\
\hline Geographic location ... & The same as for $5081-\mathrm{CO}$. \\
\hline Coordinates & Do. \\
\hline & $\begin{array}{l}\text { Curdsville Limestone Member, Lex } \\
\text { Limestone. }\end{array}$ \\
\hline
\end{tabular}

Stratigraphic position ... $1 \mathrm{ft}$ above the Tyrone Limestone-Lexing-

Silicified ton Limestone contact.

Section name

Section number

Collection number $6035-\mathrm{CO}^{*}$

Geographic location ..... Roadcut on New Watts Mill Rd., $0.1 \mathrm{mi}$ SW. of intersection with State Route 39.

Coordinates Base of section at $260 \mathrm{~mm}$ east, $346 \mathrm{~mm}$ north.

Formation.......-... Tyrone Limestone.

Stratigraphic position ... $89-94 \mathrm{ft}$ above base of section.

Silicified _..._......... Yes (335 lbs).

Quadrangle name _..._... Little Hickman, Ky.

Section name

Collection number -.----- 6036-CO*.

Geographic location ..... The same as for 6035-CO.

Coordinates Do.

Formation ............... Tyrone Limestone.

Stratigraphic position ... $80-84 \mathrm{ft}$ above base of section.

Silicified ............. Yes (418 lbs).

Quadrangle name ......... Little Hickman, Ky.

Section name............... Little Hickman A.

Collection number _.-.-.- 6037-CO*.

Geographic location -..- The same as for 6035-CO.

Coordinates Do.

Formation

Stratigraphic position

Silicified .............. Yes (178 lbs).

Quadrangle name _....... Little Hickman, Ky.

Section name.....-.-.-.- Little Hickman A.

Collection number ------- 6039-CO*.

Geographic location -..-. The same as for 6035-CO.

Coordinates Do.

Formation _......... Tyrone Limestone.

Stratigraphic position

Silicified .....-..... Yes (32 lbs).

Quadrangle name _....... Little Hickman, Ky.

Section name
Collection number ....... 6041-CO.

Geographic location ..... The same as for 6035-CO.

Coordinates .-.--.-- Do.

Formation -..--_-_--. Tyrone Limestone.

Stratigraphic position ... $38 \mathrm{ft}$ above base of section.

Silicified _...-.-.-... Yes (6 lbs).

Quadrangle name _...... Little Hickman, Ky.

Section name

Collection number _-_.-- 6042-CO.

Geographic location -..-. The same as for 6035-CO.

Coordinates .......-... Do.

Formation

Stratigraphic position _.. $35 \mathrm{ft}$ above base of section.

Silicified .............. Yes (6 lbs).

Quadrangle name _...-... Little Hickman, $\mathrm{Ky}$.

Section name

Collection number .......- 6043-CO*.

Geographic location ..... The same as for 6035-CO.

Coordinates .-.-.-.-.-. Do.

Formation

Stratigraphic position .-. $25 \mathrm{ft}$ above base of section.

Silicified

Quadrangle name

Section name _........... Little Hickman A.

Collection number -...-.- 6133-CO

Geographic location -..-- The same as for 6134-CO.

Coordinates ..-..-..- Do.

Formation ............... Tyrone Limestone.

Stratigraphic position ... 6 in. below Tyrone Limestone-Lexington Limestone contact.

Silicified ............. Yes (38 lbs).

Quadrangle name ......... Bryantsville, Ky.

Section name

Collection number - _.-- 6715-CO.

Geographic location ...-. The same as for D-1169-CO.

Coordinates ---------- Do.

Formation -.- Clays Ferry Formation.

Stratigraphic position _.. $19 \mathrm{ft}$ above base of formation.

Quadrangle name _._-_.-_ Ford, Ky.

Section name

Section number -..-..-.-. 22.

Collection number

Geographic location -.--. The same as for 5072-CO.

Coordinates .........-. Do.

Formation Member, Lexington Limestone.

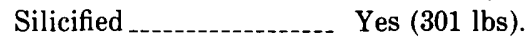

Quadrangle name

Section name

Section number -..----- 87.

Collection number ------- 7783-CO.

Geographic location ...-. The same as for 5095-CO.

Coordinates . - Do.

Formation wood Limestone Member (Tongue), Lexington Limestone.

Stratigraphic position _... Just below Devils Hollow Member, Lexington Limestone.

Silicified _......-. Yes (141 lbs).

Quadrangle name ........ Frankfort East, Ky.

Section name

Section number -..--- 86. 
Collection number --.-- 7787-CO.

Note: Recollection of 7783-CO.

Collection number 7794-CO.

Geographic location _..-- Roadcut on U.S. Route 227, just northeast of bridge crossing of Kentucky River.

Coordinates $397 \mathrm{~mm}$ east, $154 \mathrm{~mm}$ north.

Formation Oregon Formation.

Stratigraphic position ... $112 \mathrm{ft}$ below base Tyrone Limestone, $8 \mathrm{ft}$ above base Oregon Formation.

Quadrangle nam Ford, Ky.

Section name............. Daniel Boone Inn.

Collection number

Geographic location -..-- The same as for 7794-CO

Coordinates Do.

Formation _........ Tyrone Limestone.

Stratigraphic position ... $65 \mathrm{ft}$ below top of Tyrone Limestone, $15 \mathrm{ft}$ above top of Oregon Formation.

Quadrangle name

Section name _........ Daniel Boone Inn.

Collection number

$7796-\mathrm{CO}$

Geographic location ...... Interstate Route $75,1.3 \mathrm{mi}$ south of exit to State Route 418 .

Coordinates $434 \mathrm{~mm}$ east, $313 \mathrm{~mm}$ north

Formation

Lowermost part of the Tanglewood Limestone Member (Tongue), Lexington Limestone.

Stratigraphic position _-. 3-9 ft above base Cane Run Bed of the Grier Limestone Member, Lexington Limestone.

Silicified _-.---.---.-. Yes (175 lbs)

Quadrangle name

Collection number

7802-CO.

Geographic location

Roadcut $1.3 \mathrm{mi}$ south of junction of U.S. Route 27 and State Route 227, south of Richmond, Ind.

Coordinates $347 \mathrm{~mm}$ east, $168 \mathrm{~mm}$ north.

Formation Whitewater Formation.

Stratigraphic position

Quadrangle name Richmond, Ind.

Collection number

7811-CO.

Geographic location …- The same as for $6945-\mathrm{CO}$

Coordinates Do.

Formation

Tanglewood Limestone Member, Lexington Limestone.

Stratigraphic position ... $32 \mathrm{ft}$ above Brannon Member-Tanglewood Limestone Member contact, Lexington Limestone.

Silicified Yes $(117 \mathrm{lbs})$

Quadrangle name _. Ford, $\mathrm{Ky}$

Section name

Ford-Boonesboro Rd

Collection number

Geographic location

7817-CO.

Roadcut on State Route 39, $0.3 \mathrm{mi}$ southeast of Black Bridge crossing of Hickman Creek.

Coordinates

$269 \mathrm{~mm}$ east, $280 \mathrm{~mm}$ north

Formation

Curdsville Limestone Member, Lexington Limestone.

Stratigraphic position ... 6 in. above Tyrone Limestone-Curdsville Limestone Member contact.

Silicified Yes (17 lbs).
Quadrangle name Little Hickman, Ky.

Section name. Little Hickman A.

Collection number 7821-CO

Geographic location

Coordinates

Formation

Silicified

Quadrangle name

Collection number

Geographic location

Coordinates

Formation

Silicified

Quadrangle name

Collection number

Geographic location

Coordinates

Formation

Stratigraphic position

Silicified

Quadrangle name

Collection number

Geographic location

Coordinates

Formation

Stratigraphic position

Silicified

Quadrangle name

Collection number

Geographic location

Coordinates

Formation

Stratigraphic position

Silicified

Quadrangle name

Section name

Collection number

Geographic location

Coordinates

Formation

Stratigraphic position

Silicified

Quadrangle name

Section name

Collection number

Geographic location
Roadcut on U.S. Route $27,0.5$ mi northeast of junction with State Route 152. $433 \mathrm{~mm}$ east, $518 \mathrm{~mm}$ north.

Tanglewood Limestone Member, Lexington Limestone.

Yes (29 lbs).

Bryantsville, $\mathrm{Ky}$

7823-CO.

Roadcut on State Route 35, 0.6 mi northeast of junction with State Route 355 .

$16 \mathrm{~mm}$ east, $273 \mathrm{~mm}$ north.

Lower part of the Tanglewood Limestone Member, Lexington Limestone. Yes (68 lbs).

Monterey, Ky.

7824-CO

Roadcut on U.S. Route $42,0.5 \mathrm{mi}$ west of mouth of Sugar Creek to $0.5 \mathrm{mi}$ east of mouth of Creek.

$203 \mathrm{~mm}$ east, $139 \mathrm{~mm}$ north

Point Pleasant Tongue, Clays Ferry Formation.

$3 \mathrm{ft}$ above base of exposure, $20-25 \mathrm{ft}$ below Point Pleasant Tongue-Kope Formation contact.

Yes (154 lbs).

Patriot, Ky.-Ind.

7825-C0.

The same as for $7824-\mathrm{CO}$.

$$
\text { Do. }
$$

Point Pleasant Tongue, Clays Ferry Formation.

$3 \mathrm{ft}$ below Point Pleasant Tongue-Kope Formation contact.

Yes (231 lbs).

Patriot, Ky.-Ind.

$7830-\mathrm{CO}$

The same as for 6211-CO.

$$
\text { Do. }
$$

Point Pleasant Tongue, Clays Ferry Formation.

Float in lower $10 \mathrm{ft}$ of gully on east wall.

Yes (22 lbs)

Moscow, Ohio-Ky.

Bear Creek.

$7835-\mathrm{CO}$

The same as for $7836-\mathrm{CO}$.

$$
\text { Do. }
$$

Camp Nelson Limestone.

Float at base of section.

Yes (15 lbs).

Little Hickman, Ky.

Type section Camp Nelson Limestone.

$7842-\mathrm{CO}$

Quarry on U.S. Route 150 about $2.4 \mathrm{mi}$ southeast of Danville. 
Coordinates

Formation

Quadrangle name

Section name

Collection number Geographic location

Coordinates

Formation

Silicified

Quadrangle name

Collection number

Geographic location

Coordinates

Formation

Stratigraphic position

Quadrangle name

Section name

Collection number

Geographic location ...

Coordinates

Formation

Stratigraphic position

Quadrangle name

Section name

Collection number

Geographic location

Coordinates

Formation

Stratigraphic position

Quadrangle name

Section name

$18.5 \mathrm{~mm}$ east, $9.5 \mathrm{~mm}$ north.

Cornishville Bed, Perryville Limestone

Member, Lexington Limestone.

Bryantsville, Ky.

Caldwell Stone Quarry.

7843-CO.

Roadcut on U.S. Route 127 (State Route 35) about $2.5 \mathrm{mi}$ north of Moreland.

$260 \mathrm{~mm}$ east, $173.5 \mathrm{~mm}$ north.

Ashlock Formation.

Yes (450 lbs).

Junction City, Ky.

7863-CO.

The same as for 5079-CO.

Do.

Camp Nelson Limestone.

$5.1 \mathrm{ft}$ above base of section.

Wilmore, Ky.

High Bridge.

7885-CO.

The same as for $7875-\mathrm{CO}$

Do.

Camp Nelson Limestone.

$102 \mathrm{ft}$ above base of section.

Wilmore, Ky.

High Bridge.

Collection number

Geographic location

Coordinates

Formation

Stratigraphic position

Quadrangle name

Section name.

Section number

7886-CO

The same as for $7875-\mathrm{CO}$.

Do.

Tyrone Limestone.

$210 \mathrm{ft}$ above base of section.

Wilmore, Ky.

High Bridge.

D-1202-CO*.

The same as for D-1200-CO.

Do.

Brannon Member, Lexington Limestone. $215 \mathrm{ft}$ above base of section.

Frankfort East, Ky.

Frankfort East A.

86.

Collection number

Geographic location

D-1206-CO*.

Coordinates

Formation

The same as for D-1200-CO.

$$
\text { Do. }
$$

Tanglewood Limestone Member, Lexington Limestone.

Stratigraphic position Quadrangle name

Section name

Section number $247 \mathrm{ft}$ above base of section.

Frankfort East, Ky. Frankfort East A. 86.

\section{REFERENCES CITED}

Bassler, R. S., 1932, The stratigraphy of the central basin of Tennessee: Tennessee Division of Geology Bull. 38, 268 p., 49 pls.

_ 1938, Pelmatozoa Palaeozoica, Pt. 83 of Quenstedt, W., ed., Fossilium Catalogus. I. Animalia: 's-Gravenhage, Netherlands, W. Junk, $194 \mathrm{p}$.

Bassler, R. S., and Moodey, M. W., 1943, Bibliographic and faunal index of Paleozoic pelmatozoan echinoderms: Geological Society of America Special Paper 45, 734 p.
Bather, F. A., 1899, A phylogenetic classification of the Pelmatozoa: British Association for the Advancement of Science, Report of 68th Meeting, Bristol, 1898, p. 916-923.

-1900, The Echinoderma, v. 3 of Lankester, E. R., ed., Treatise on zoology: London, 344 p. (See the Cystidea, p. 38-77.)

Bell, B. M., 1979, Edrioasteroids (Echinodermata): U.S. Geological Survey Professional Paper 1066-E, 7 p., 2 pls.

Billings, Elkanah, 1854, On some new genera and species of Cystidea from the Trenton Limestone: Canadian Journal, v. 2, p. 215-218, 250-253, 268-274.

- 1857, Report for the year 1856: Canada Geological Survey, Report of Progress 1853-1856, p. 245-345.

1858, Figures and descriptions of Canadian organic remains: Canada Geological Survey, Canadian Organic Remains, Decade 3, p. 9-102, pls. 1-11.

Billings, W. R., 1883, Notes on and description of, some fossils from the Trenton Limestone: Ottawa Field Naturalists' Club Transactions no. 4, p. 49-52, 1 pl.

Branstrator, J. W., 1979, Asteroidea (Echinodermata): U.S. Geological Survey Professional Paper 1066-F, 7 p., 3 pls.

Broadhead, T. W., 1974, Reevaluation of the morphology of Amecystis laevis (Raymond): Journal of Paleontology, v. 48, no. 4, p. 670-673.

Broadhead,T. W., and Strimple, H.L., 1975, Respiration in a vagrant Ordovician cystoid, Amecystis: Paleobiology, v. 1, no. 3, p. 312-319, 3 figs.

Buch, Leopold von, 1846, Uber Cystideen eingeleitet durch die Entwicklung der Eigenthumlichkeiten von Caryocrinus ornatus Say. Gelesen in der Akademie der Wissenschaften am 14 Mai 1844: Akademie der Wissenschaften Berlin, Abhandlungen 1844, p. 89-116, pls. 1-2.

Carpenter, P. H., 1882, On the relations of Hybocrinus, Baerocrinus, and Hybocystites: Geological Society of London Quarterly Journal, v. 38 , p. 298-312, 1 pl., figs. 1-3.

Caster, K. E., 1952, Concerning Enoploura of the Upper Ordovician and its relation to other carpoid Echinodermata: Bulletins of American Paleontology, v. 34, no. 141, 56 p., 4 pls.

Gill, E. D., and Caster, K. E., 1960, Carpoid echinoderms from the Silurian and Devonian of Australia: Bulletins of American Paleontology, v. 41, no. 185,60 .p.

Haeckel, Ernst, 1896, Die Amphorideen und Cystoideen; Beiträge zur Morphologie und Phylogenie der Echinodermen: [Leipzig, W. Engelmann], 179 p., 5 pls., 25 figs. (Festschrift zur 70 Geburtstages von Carl Gegenbaur, Bd. 1.)

Hall, James, 1872, Description of new species of Crinoidea and other fossils from strata of the age of the Hudson River Group and Trenton Limestone: New York State Museum of Natural History Annual Report 24, p. 205-224, pls. 5-8.

Jaekel, Otto, 1900, Ueber Carpoideen, eine neue Classe von Pelmatozoen: Deutsche Geologische Gesellschaft Zeitschrift, v. 52, no. 4, p. 661-677, figs. 1-11.

_- 1918, Phylogenie und System der Pelmatozoen: Palaeontologische Zeitschrift, v. 3, no. 1, p. 1-128, figs. 1-114 [1921].

Kesling, R. V., 1961, A new Glyptocystites from Middle Ordovician strata of Michigan: Michigan University Museum of Paleontology Contributions, v. 17 , no. 2, p. 59-76, pls. 1-3, figs. 1-4.

Matsumoto, H., 1929, Outline of a classification of Echinodermata: Tohoku Imperial University Science Reports, 2d ser. (Geology), v. 13 , no. 2 , p. $27-33$.

Miller, J. S., 1821, A natural history of the Crinoidea or lily-shaped animals; with observations on the genera Asteria, Euryale, Comatula, and Marsupites: Bristol, published for the author by C. Frost, p. 1-150.

Miller, S. A., 1889-1897, North American geology and paleontology: Cincinnati, Ohio, 664 p. (1889); first appendix, p. 665-718 (1892); second appendix, p. 719-793 (1897).

Miller, S. A., and Gurley, W. F. E., 1895, Description of some new species of Paleozoic Echinodermata: Illinois State Museum of Natural History Bulletin 6, 62 p., 5 pls. 
Moore, R. C., and Laudon, L. R., 1943, Evolution and classification of Paleozoic crinoids: Geological Society of America Special Paper 46,153 p., 14 pls., 18 figs.

Neumayr, Melchior, 1889, Die Stämme des Thierreiches. Bd. l. Wirbellose Thiere: Vienna and Prague, F. Tempsky, $1 \mathrm{v}$.

Orbigny, Alcide, d', 1849-1852, Prodrome de paleontologie stratigraphique universelle des animaux mollusques et rayonnés: Paris, Victor Masson, $3 \mathrm{v}$.

Parks, W. A., 1908, On an occurrence of Hybocystis in Ontario: Ottawa Naturalist, v. 21, p. 232-236, 1 pl.

Parsley, R. L., 1967, Morphology and function of the aulacophore in the mitrate carpoid, Enoploura (Echinodermata; Middle and Upper Ordovician): Geological Society of America, Annual Meeting, New Orleans, 1967, Program with Abstracts, p. 172-173. -1969, Studies in Middle Ordovician primitive Echinodermata: Cincinnati, Ohio, University of Cincinnati, $\mathrm{Ph}$. D. dissertation, $322 \mathrm{p}$.

1970, Revision of the North American Pleurocystitidae (Rhombifera-Cystoidea): Bulletins of American Paleontology, v. 58 , no. 260 , p. $135-213$.

Parsley, R. L., and Caster, K. E., 1975, Zoological affinities and functional morphology of the Mitrata (Echinodermata) [abs.]: Geological Society of America, Abstracts with Programs, v. 7, no. 7, p. 1225-1226.

Parsley, R. L., and Mintz, L. W., 1975, North American Paracrinoidea: (Ordovician: Paracrinozoa, New, Echinodermata): Bulletins of American Paleontology, v. 68, no. 288, p. 1-115, pls. 1-13, figs. 1-8.

Paul, C. R. C., 1967, The functional morphology and mode of life of the cystoid Pleurocystites E. Billings, 1854, in Millott, N., ed., Echinoderm biology: Zoological Society of London Symposia no. 20, p. $105-123$.

Pojeta, John, Jr., 1979, The Ordovician paleontology of Kentucky and nearby States-Introduction: U.S. Geological Survey Professional Paper 1066-A, 48 p.

Raymond, P. E., 1921, A contribution to the description of the fauna of the Trenton Group: Canada Geological Survey, Museum Bulletin 31,64 p., 11 pls.

Regnéll, Gerhard, 1945, Non-crinoid Pelmatozoa from the Paleozoic of Sweden: Lunds Geologisk-Mineralogiska Institution Meddelanden no. 108,255 p., 15 pls, 30 figs.
Salter, J. W., and Billings, Elkanah, 1858, On Cyclocystoides, a new genus of Echinodermata from the Lower and Middle Silurian rocks: Canada Geological Survey, Canadian Organic Remains, Decade 3, p. 86-90, pl. 10.

Sinclair, G. W., 1948, Three notes on Ordovician cystids: Journal of Paleontology, v. 22, no. 3, p. 301-314, pls. 42-44, figs. 1-6.

Springer, Frank, 1911, On a Trenton echinoderm fauna at Kirkfield, Ontario: Canada Geological Survey Memoir 15, 68 p., 5 pls., 3 figs.

Ubaghs, Georges, 1967, Stylophora, in Moore, R. C., ed., Treatise on invertebrate paleontology, Pt. S, Echinodermata 1, v. 2: New York and Lawrence, Kans., Geological Society of America and University of Kansas Press, p. S495-S565 [1968].

Ulrich, E. O., and Kirk, Edwin, 1921, Amecystis, a new genus of Ordovician Cystidea: Biological Society of Washington Proceedings, v. 34 , p. $147-148$.

Wachsmuth, Charles, and Springer, Frank, 1885, Revision of the Palaeocrinoidea, pt. 3, sec. 1: Academy of Natural Sciences of Philadelphia Proceedings, 1885, p. 225-364, pls. 4-9.

Wetherby, A. G., 1879, Description of a new family and genus of Lower Silurian Crustacea: Cincinnati Society of Natural History Journal, v. 1 (Jan.), p. 162-166; v. 2 (Apr.), pl. 7, figs. 1-1g.

- 1880, Remarks on the Trenton Limestone of Kentucky, with descriptions of new fossils from that formation and the Kaskaskia (Chester) Group, Subcarboniferous: Cincinnati Society of Natural History Journal, v. 3, p. 144-160, 1 pl.

- 1881, Descriptions of new fossils from the Lower Silurian and Subcarboniferous rocks of Kentucky: Cincinnati Society of Natural History Journal, v. 4, p. 177-179, pl. 5.

Whitehouse, F. W., 1941, The Cambrian faunas of northeastern Australia; Pt. 4, Early Cambrian echinoderms similar to the larval stages of Recent forms: Queensland Museum Memoirs, v. 12, pt. 1, 28 p., 4 pls.

Wilson, A. E., 1946, Echinodermata of the Ottawa Formation of the Ottawa-St. Lawrence Lowland: Canada Geological Survey Bulletin 4,61 p., 6 pls.

Zittel, K. A., 1879, Handbuch der Palaeontologie; [Pt.] 1, Palaeozoologie: Munich, R. Oldenbourg, 4 v. (See especially Echinodermata in v. 1, p. $308-560$.) 


\section{PLATE 1}

Contact photograph of this plate in this report is available at cost, from U.S. Geological Survey Library, Federal Center, Denver, Colorado 80225. 


\section{PLATE 1}

FIGURE 1. Amecystis laevis (Raymond), 1921 (p. K2).

Ventral (anal) face of the theca and part of the column. Note the sculpture of the marginal plates and the tesselated periproct. Edinburg Formation, Tumbling Run, near Strasburg, Va. USNM 245181; (X 1.75).

2,3. Amygdalocystites forealis Billings, 1854 (p. K3).

Both specimens are from USGS locality 6134-CO, Curdsville Limestone Member, Lexington Limestone.

2. Anterior face of the theca with the recumbent arms and curved proximal part of the column attached. The actual plate ornamentation is not preserved. USNM 245182; (X 1.5).

3. Posterior face of the theca with the curved proximal part of the column and recumbent arms attached. The pinnules on the left arm are preserved lying on the theca. USNM 245183; (X 2).

4,13. Cupulocrinus sp. (p. K4).

Both specimens are from USGS locality 5072-CO, Curdsville Limestone Member, Lexington Limestone.

4. The dorsal cup and proximal parts of the arms (two pieces). USNM 245184; (X 2).

13. Poorly preserved theca and proximal parts of the arms. USNM 245192; (X 1.5).

5. Heterocrinus sp. (p. K4).

Thecal cup with part of the column and the proximal parts of the arms attached. USGS locality 4946-CO, Grier Limestone Member, Lexington Limestone. USNM 245185; (X 3).

6, 9. Hybocrinus tumidus Billings, 1857 (p. K3).

Two views of a poorly preserved theca. Note the crenulated anal (X) plate in fig. 9. USGS locality 5083-CO, Curdsville Limestone Member, Lexington Limestone. USNM 245186; (X 2).

7, 8, 10. Hybocystites problematicus Wetherby, 1880 (p. K4).

Specimens for figs. 7 and 10 from USGS locality 5083-CO, Curdsville Limestone Member, Lexington Limestone. Specimen for fig. 8 from USGS locality 7785-CO, Curdsville Limestone Member, Lexington Limestone.

7. Incomplete theca with a prominent radial plate. USNM 245187; (X 2).

8. Disarticulated radial plate. USNM 245188; (X 2).

10. Poorly preserved but essentially complete theca; note the radial plate with the arm base. USNM 245189; (X 2).

11, 12. Carabocrinus sp. (p. K4).

Both specimens from USGS locality 7785-CO, Curdsville Limestone Member, Lexington Limestone.

11. Radial plate. USNM 245190; (X 2).

12. Basal plate. USNM 245191; (X 2).

14-19. Enoploura cf. E. punctata Bassler, 1932 (p. K2).

Specimens shown in figs. 14-17 are from USGS locality 6134-CO, Curdsville Limestone Member, Lexington Limestone.

14. Poorly preserved incomplete carapace surface of the theca. USNM 245193; (X 3).

15. Incomplete carapace surface of the theca. USNM 245194; (X 2.5).

16. Incomplete theca with poorly preserved internal surface of the plastron face exposed. USNM 245195; (X 3).

17. Theca with plastron surface exposed, articulating spines and proximal aulacophore attached. The animal is on the inner surface of a shell of the brachiopod Rafinesquina. USNM 247881; (X 2.5).

18. Fragmentary remains of a theca and proximal aulacophore on the undersurface of a shell of the brachiopod Rafinesquina. USGS locality 6143-CO, Clays Ferry Formation. USNM 247882; (X 2).

19. Articulating spine, lateral view. SEM photo. USGS locality 7785-CO, Curdsville Limestone Member, Lexington Limestone. USNM 247883; (X 18).

20. Cyclocystoides sp. (p. K5).

Distal view of a single submarginal plate with two radial ducts. SEM photo. USGS locality 5015-C0, Salvisa Bed, Perryville Limestone Member, Lexington Limestone. USNM 247884; (X 23). 

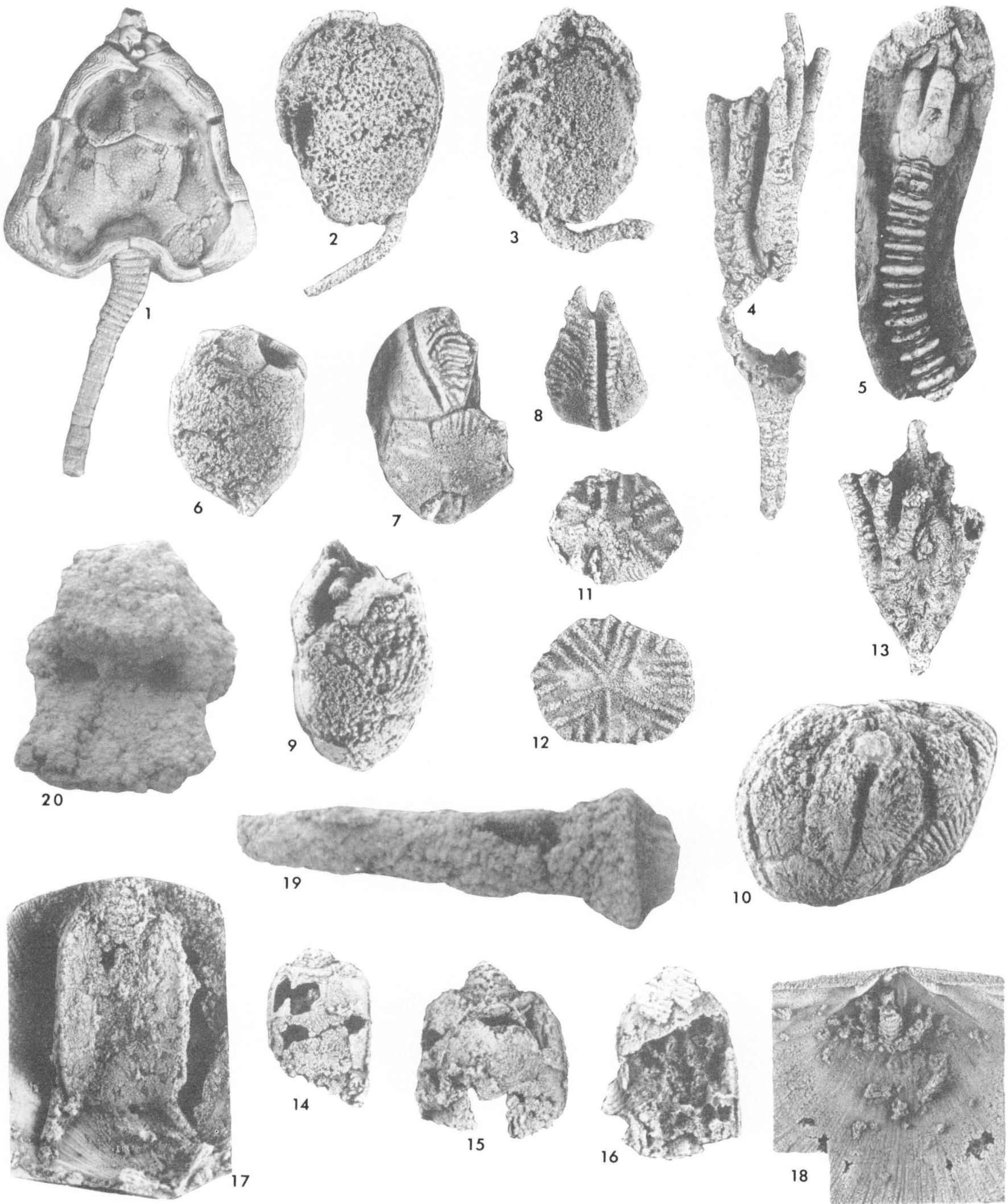

AMECYSTIS, AMYGDALOCYSTITES, CUPULOCRINUS, HETEROCRINUS, HYBOCRINUS, HYBOCYSTITES, CARABOCRINUS, ENOPLOURA, AND CYCLOCYSTOIDES 
